\title{
INNOVATIVE LEADER IN HIGHER EDUCATION
}

\section{Vytautas Katasanovas, Vidmantas Katasanovas, Žilvinas Stankevičius}

\author{
Lithuanian Sports University, Kaunas, Lithuania
}

\begin{abstract}
ANNOTATION
Changing higher education environment, global competition of universities and colleges create a need to react to the changes in the labour market; higher education organizations must implement innovations that help improving effectiveness. The object of the research was the innovative leader in higher education. The purpose of the research was to identify the main roles of innovative leader in higher education and determine how they manifest at higher education institution "Kauno kolegija". This article presents theoretical analysis of innovative leader roles in higher education institution, and empirical research revealing roles of innovative leaders in the case of "Kauno kolegija".
\end{abstract}

Keywords: innovative leader, innovation, higher education, higher education institution.

\section{INTRODUCTION}

Research problem. In recent years leadership processes have become very important in different spheres of activity. Higher education in Lithuania faces some important challenges that are also important for universities and colleges in other countries: changing higher education environment, global competition of universities and colleges, need to react to the changes in labour market and prepare specialists that correspond to these changes, need to make universities and colleges more process - efficient. Leaders must take their role in this process, and it is important to identify their roles in the context of innovations. Problem analysed in this research is what the roles of innovative leader in higher education are theoretically, and what the level of innovative leadership in Lithuanian higher education institution "Kauno kolegija" is.

Level of previous researches. Challenges of higher education in the context of leadership were distinguished and researched previously. One of the traits of effective leadership is innovative leadership in higher education organization that is especially oriented towards implementing changes in universities and colleges. Leadership is important in creative and innovative endeavours (Stenmark et al., 2011), and the importance of leaders that help universities and colleges to cope with a need for innovations is determined in recent scientific research (Morgan, Mulligan, 2014; Yagging et al., 2015). These studies present different views towards the problem.

Novelty of research. It is important to identify what are the roles of innovative leader in higher education, and to research the level of innovative leadership in Lithuanian higher education organizations. The novelty of research is the generalized theoretical scheme of role of innovative leader in higher education organization, and the original research performed in higher education organization "Kauno kolegija".

Main scientific researches. Important issues were analysed by J. Morgan, C. T. Mulligan (2014), L. M. Basham (2012), D. Cantwell, I. Kaupinnen (2014) and other scientists that emphasize the importance of effective leadership in higher education institutions. 
The purpose of the research was to identify the main roles of innovative leader in higher education and to determine how they manifest at higher education institution "Kauno kolegija". The object of the research was the innovative leader in higher education.

\section{RESEARCH METHODS}

Methods of analysis and systemising were used performing theoretical literature analysis. Method of questionnaire survey was used to perform an empirical research, that is, to evaluate how roles of innovative leader manifest at higher education institution "Kauno kolegija". In order to perform the research, the questionnaire form was developed, including the main aspects of role of innovative leader in higher education, summarised according to theoretical literature analysis (as presented in Figure 1). Respondents are asked to state their agreement or disagreement to the statements describing innovative leader roles on a five-point Likert scale ranging from "strongly disagree" to "strongly agree". The statements of demographic characteristics (sex, age, work experience) were also included in the questionnaire. The research sample was the lectors of "Kauno kolegija" ( $\mathrm{N}=365), 49$ lectors were questioned. According to such number of respondents, this research should be considered as a pilot research. Data was collected in May, 2016, presenting questionnaire form for lectors in printed and electronic form. Results were analysed using MS Excel and SPSS. 17 software.

Validity of the questionnaire form was tested using the index of Cronbach's Alpha. The alpha value of 0.65 of higher was considered as an acceptable level of reliability. Cronbach alpha reveal that instrument is reliable, as Cronbach's Alpha $=0.76$.

\section{RESEARCH RESULTS AND DISCUSSION}

Concept and characteristics of innovative leader. In scientific literature leadership is described as "taking responsibilities and making choices on your own" (Varol, A., Varol, S., 2012, p. 281). In scientific literature concept of innovative leader is related to the concept of "good leader" (Basham, 2012; Morgan, Mulligan, 2014), remarking that a good leader "promotes an inspiring vision accompanies by a set of clear and consistent goals, which they continuously communicate throughout the organization" (Martinez, Wolverton, 2009). According to R. W. Elliott, V. O. Paton (2014), "leadership is a process that is ultimately concerned with fostering change...it implies a process where there is movement", which "also implies intentionality, in a sense that the implied change is not random...but is rather directed toward some future end or condition which is desired or valued" (p. 2). It may be concluded that that essence of leadership itself is related to the idea of innovation and changes.

The concept of innovative leader is related to the classical concept of transformational leadership that is understood as "a type of leadership style that leads to positive changes in those who follow. The concept itself focuses on a leader who actually changes the needs of organizations. It also motivates the followers to perform high level performance as well as it helps them to improve their own leadership potential” (Basham, 2012, p. 18). Transformational leaders have such traits (Varol, A., Varol, S., 2012): 
- Idealized influence; it contains building confidence and trust as well as providing a role model that followers seek to emulate;

- Inspirational motivation: the ability for a leader to provide meaning and context to the work of those under him/her;

-Intellectual stimulation: the ability for a leader to keep those following him or her thinking about the task at hand, asking questions, solving problems

- Individualized consideration: organizations need individuals to fulfil the changes; the personalities of these individuals show diversity and they cannot be altered much.

Innovative leader should be transformational leader's role, but he/she also must do something more. He must be especially oriented towards innovation management. Innovation management „,consists of the economic implementation and exploitation of new ideas and discoveries” (Vlăsceanu, 2013, p. 706), and a leader in the context of innovation management must be capable of ,,mobilizing, convincing, training, and encouraging his team in order to achieve their goals" (Weiss, Legrand, 2011, p. 45). Ch. Vlăsceanu (2013) identifies such main traits of innovative leader:

- a leader has to be able to mobilize and motivate the team and make it aim towards "new";

- a leader has to have the abilities and qualities in order to push for innovation in the activity field of the organization.

Such a leader is not the main "innovator" in the organization, but be creates an environment that inspires and stimulates organization and its members to innovate. Such leader is able to form goals in organization related to innovations, and help organization's members to achieve them. $\mathrm{He} / \mathrm{she}$ helps every member of organization to contribute to the main innovation process (Basham, 2012).

Besides that, innovative leader should take some part in the innovation process itself. According to Ch. K. Stenmark, A. S. Shipman, M. D. Mumford (2011), planning for innovation is held to occur across five stages: (a) scanning, (b) template planning, (c) plan development, (d) forecasting, and (e) plan execution. At each stage, leaders must engage in qualitatively different planning activities and consider different issues and requirements. Leaders must be adaptable and be able to make these changes as projects move through each of the stages.

So it may be said that innovative leader is not only a person who works with an innovation itself (helping to scan, plan the template, develop plan; forecast, executing plan), but also a person who works with people in the context of innovation process, inspiring them to innovation, crating and environment that stimulates innovations, and helping organization's members to find ways to work together finding meaningful ways to make important changes in the organization.

Role of leaders in the context of higher education. Concept of innovative leader is especially important in organizations that face a need for continuous innovations. Peculiarities of such organizations require leaders that could drive organization through important changes, to appear (Weiss, Legrand, 2011). Higher education is a sort of "knowledge industry" (Martinez, Wolverton, 2009), knowledge is created and managed all the time there. Leaders of colleges and universities lead personnel that consist of well-educated and clever peoples, ant they must know how to coordinate their common efforts creating a better and more innovative educational surrounding, improving the 
state of academic society. The quality of higher education itself depends upon the precipitancy of separate higher education organization (Basham, 2012).

Innovations have become important in universities and colleges since higher education organizations have become market-driven, oriented towards entrepreneurial behaviour; and a socalled academic capitalism regime appeared (McClure, 2016). Universities are considered to be some kind of producers (Cantwell, Kaupinnen, 2014). In such a situation administration of higher education organization must be innovative and entrepreneurial, as innovations should become "an integral part of academic culture" (McClure, 2016, p. 3). In other words, important of innovations in the context of higher education organizations are explained by the need to adapt new management methods (Carpenter, 2012), new educational methods (Morgan, Mulligan, 2014), correspond issues of current global situation (Najam et al., 2014), that is, great emigration, international labour market, global business, global researches in social, political and other spheres.

Innovation is pinned to entrepreneurship, as it is viewed as a necessary force of disruption within established sectors like higher education (Christensen, Eyring, 2011). Innovation in the context of higher education institution may have different forms. Innovative way of acting or thinking is what such leader is expected to do (Ehlers, Schneckenberg, 2010)). Such a leader should inspire an organisation to do something different - something that corresponds great challenges of our times; he should realise the vision, implementing new methods of activity and education if they are needed in order to improve the higher education institution; such a leader should support researches that are meaningful in the context of the state and in the international context; he / she should help his university and college to correspond current global challenges, for example to attract foreign students, to prepare student that are able to work in the international labour market; (Najam et al., 2014). According to R. Piemonte (2015), leader in a higher education institution should mainly perform several roles: 1) should fit in with the culture of institution and be its ambassador; 2) should be a thought leader; 3 ) should be organizational leader. Such a leader should put a universities and colleges into higher level in some way - organizational or functional.

Universities and colleges should be innovation and knowledge driven; and it is something that leaders and personnel of these organizations execute, so the innovation process is not separable from people that fulfil this process. "Successful innovation depends on focused, purposeful work that bot only benefits individuals but the institution as a whole - and this is especially true for organizations whose primary labour force share the characteristics of faculty. "(Martinez, Wolverton, 2009, p. 24). When organization is implementing innovations, the role of leaders is especially important (Yagging et al., 2015). Several types of leaders in higher education organization are identified in in relation to innovations performed in these organizations: innovation leaders (e.g. external experts), who introduce the innovation; secondary leaders (teaching team and student representative), who are involved in part of the innovations, and formal leaders (dean or course convenor) who are in a position of power and authority to support innovation. Role of formal leaders is especially important: , "success of innovations was jeopardised when the formal leaders were committees that made the decisions to introduce innovative changes recommended by the innovative leaders, without the necessary participations of the secondary leaders in the research problem - solving, or in the final 
decisions which affected their practice" (Zuber, Skerritt, 2013, p. 103). However, not only formal leaders should care about innovations, innovations could be well stimulated and initiated among main personnel as well (Basham, 2012).

It is important that separate innovative leader (formal or informal) use their knowledge and create benefit to the organization of higher education, not only their own personal curriculum vitae. Usually recognition of achievements of separate leaders goes along with recognition of organization that they represent, and vice versa (Cantwell, Kaupinnen, 2014). Personal achievement may guarantee access to better career choices in the system of higher education, but also it may be understood that this forms a reputation of higher education organization (Piemonte, 2015).

Leaders in universities and colleges should also have such traits of transformational leadership: 1) provide a clear sense of direction and purpose for the institution by creating a longterm vision; 2) Establish an environment of excellence of performance that is not an act but a habit; 3) Determine to succeed one step at a time while building momentum and practicing resilience, resulting in perseverance; 4) Demonstrate enthusiasm through positive views and an atmosphere of excitement, passion, and optimism; 5) Become focused on outcomes through advance planning, prioritizing, organizing time lines, and successfully delegating to maximize efforts; 6) Demonstrate a willingness to assume responsibility and consequences for outcomes; 7) Incorporate discipline, drive, accepting of responsibility; 8) acknowledge and influence people; 9) reflect courage through sacrifice and expecting much of themselves (Basham, 2012). However working with people in higher education may sometimes be difficult. Sometimes leaders have to lead those people that "don't want to be led and may be smarter than you" (Martinez, Wolverton, 2009, p. 29). Universities and colleges gather around people that are highly intelligent, who "know their worth, expect to be appreciated, and want to be tenured, yet demand the freedom to explore and fail" (Martinez, Wolverton, 2009, p. 30). Knowledge of universities and colleges usually is individual, not institution-specific (Martinez, Wolverton, 2009), so the success of innovation management usually depends upon how successful the work of leaders with human resources is, not only the processes of innovation planning and execution.

The summarized role of innovative leader in higher education is shown below (Figure 1). Performed analysis of scientific literature reveals that an innovative leader should play two main roles in higher education organization: first, he works with peoples and should have traits of transformational leadership, that is, his activity should involve idealized influence, inspirational motivation; intellectual stimulation, individualized consideration. Second, innovative leader should help his organizational to make the right and reasonable innovation - such that help a university or college to corresponding challenges of our times; implement new methods of activity and education; stimulate meaningful research; preparing students that are able to work in the international labour market. 

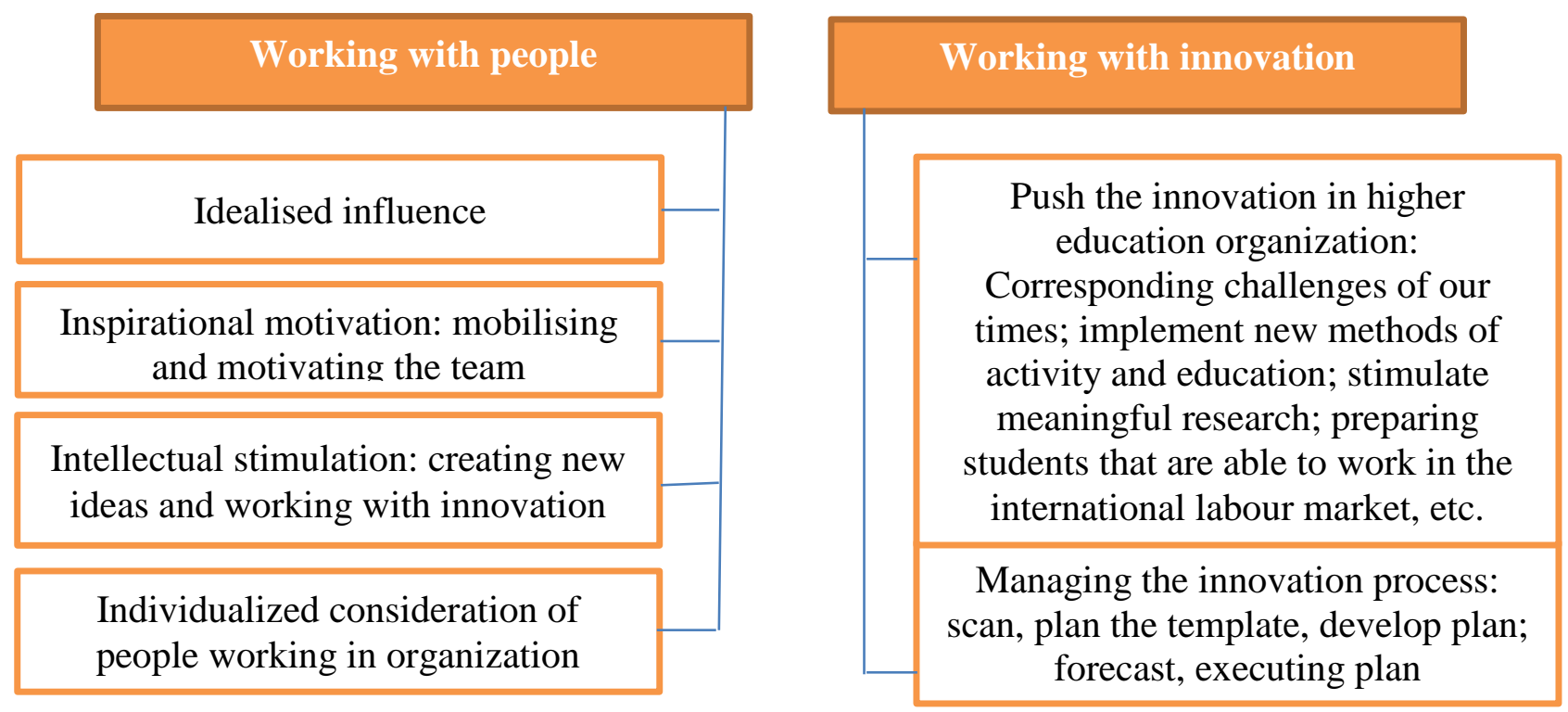

Figure 1. Theoretical scheme of the role of innovative leader in higher education institution

The roles of innovative leader in the context of Lithuania's higher education: research performed at the University of Applied Sciences "Kauno kolegija". Results of research reveal that innovations are rather an important at "Kauno kolegija", $68 \%$ of respondents notice at least some innovation efforts in recent years. According to the respondents, not only formal leaders manage innovations, but also leaders appearing among main personnel (in work groups, presenting innovations initiatives).

Results of research reveal that formal leaders do not always act like innovative leader as far as their role working with people is concerned (Figure 2). Half of respondents notice actions of idealised influence, inspirational motivation, and intellectual stimulation of individualized consideration performed by formal leaders.

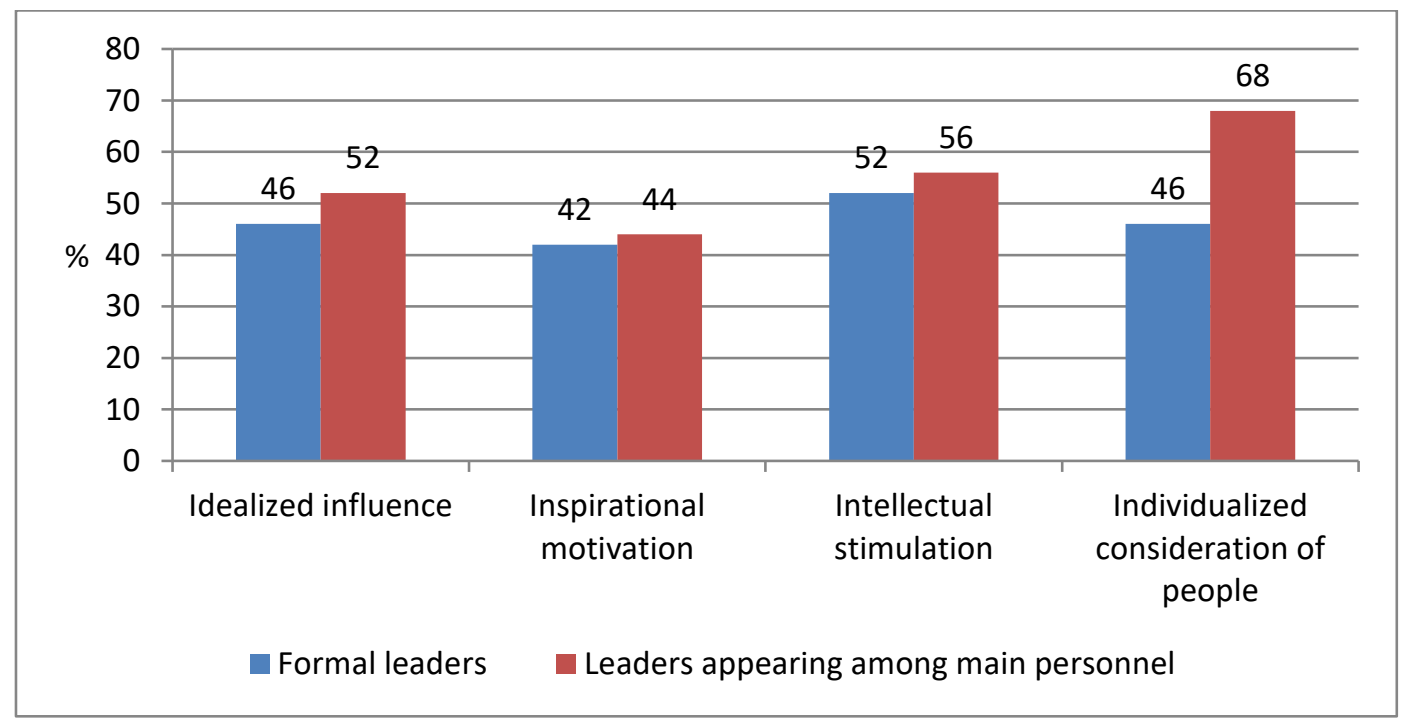

Figure 2. Characteristics of innovative leadership among formal leaders and leaders appearing among personnel 
As results reveal, leaders that appear among the main personnel more usually consider other people in organization in an individualized way, use more intellectual stimulation, idealised influence and inspirational motivation than formal leaders. It may be noticed that abilities of formal leaders to act as innovative leader and work with people as a transformational leader is not sufficient.

As far as the role of innovative leaders working in the context of innovation process is concerned, it appeared that innovative leadership characters are rather weak (Figure 3).

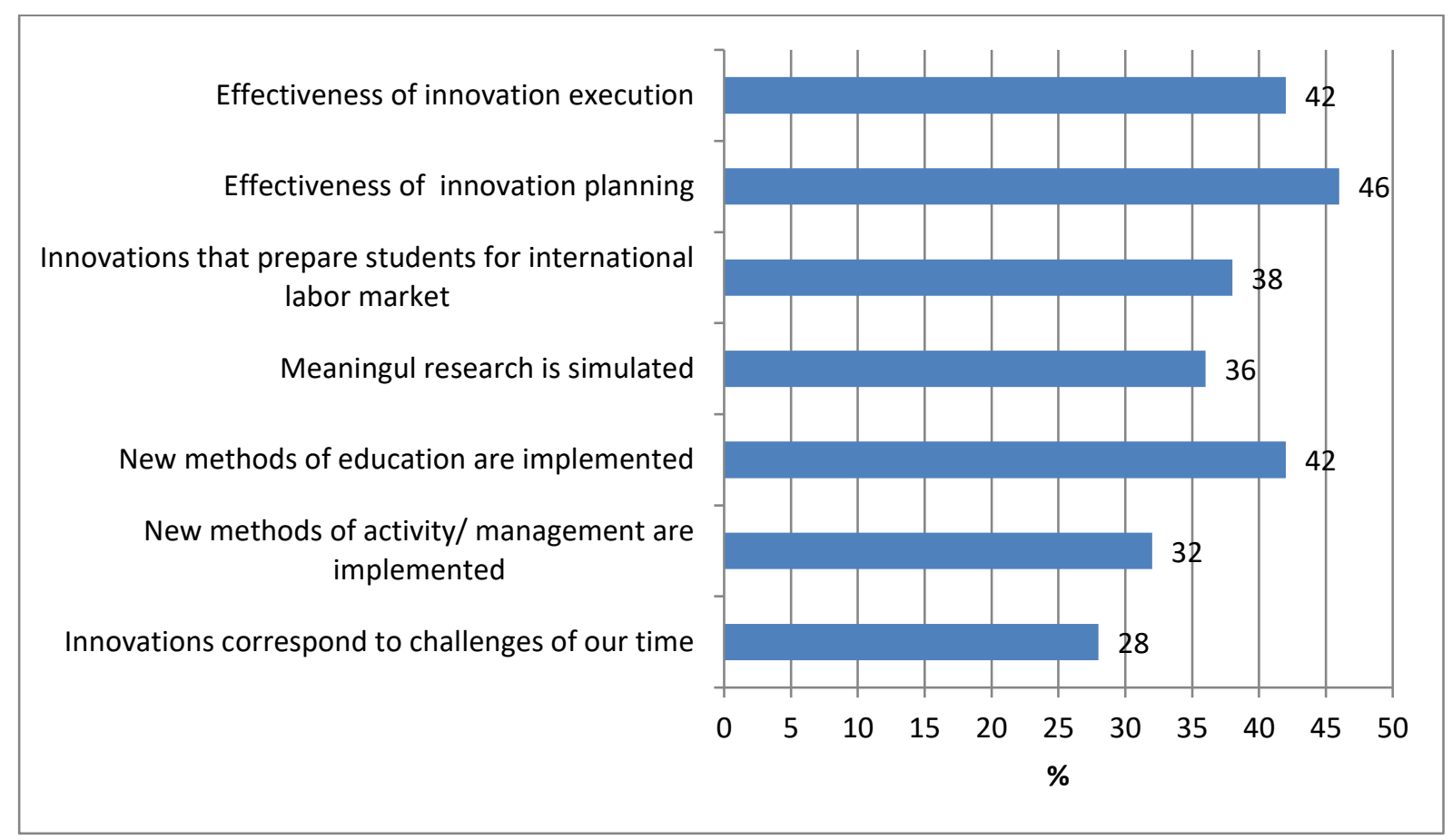

Figure 3. Role of leaders in innovation process

Less than $1 / 3$ of respondents think that leaders in "Kauno kolegija" are oriented towards implementing innovations that help organization to cope with challenges of our times $(28 \%)$, and that needed management innovation (32\%) are implemented.

Less than a half of respondents think that new methods of education are implemented (42\%), or that meaningful researches are stimulated (36\%), or that innovations helping students to become prepared for internal labour marker (38\%) are implemented.

These results reveal that innovative leadership is yet not fully implemented in "Kauno kolegija". It is important to strengthen the role of innovative leader in this higher education institution seeking to better react to the changing environment and challenges that system of higher education meet.

\section{CONCLUSIONS AND PERSPECTIVES}

1. Analysis of theoretical literature revel that innovative leader should play two main roles in higher education institution. First of all, working with people is an important part of innovative leader's agenda. Such a leader should use style of transformational leadership (idealized influence, inspirational motivation; intellectual stimulation, individualized consideration). On the other hand, innovative leader should take part in innovation process. He/she should initiate important innovations 
that would improve higher education environment (help a university or college to correspond to challenges of our times; implement new methods of activity and education; stimulate meaningful researches; implement innovations that prepare students for international and internal labour market), and also take part in planning and executing innovations.

2. Results of empirical research performed in higher education institution "Kauno kolegija" reveal that innovative leadership is yet not fully implemented in this organization. Abilities of formal leaders to act as innovative leader and work with people as a transformational leader are not sufficient. The role of innovative leaders in implementing innovations that help organization to cope with challenges of our times, management innovation, or innovations helping students to become prepared for international labour market is rather weak.

3. Perspectives of further researches in the sphere of innovative leadership are related to the need to research how innovative leadership is implemented in other Lithuanian higher education organizations.

\section{REFERENCES}

1. Basham, L. M. (2012). Transformational and transactional leaders in higher education. SAM Advanced Management Journal, Spring, 15-25.

2. Cantwell, D., Kauppinen, I. (2014). Academic capitalism in the Age of Globalization (p. p. 3-9). Baltimore: Johns Hopkins University Press.

3. Carpenter R. G. (2012). Cases on Higher Education Spaces: Innovation, Collaboration, and Technology: Innovation, Collaboration, and Technology. IGI Global.

4. Christensen, C. M., Eyring, H. J. (2011). The Innovative University: Changing the DNA of Higher Education from the Inside out. San Francisco: Jossey-Bass.

5. Ehlers, U. D., Schneckenberg, D. (2010). Changing Cultures in Higher Education: Moving Ahead to Future Learning. Springer Science \& Business Media.

6. Elliott, R. W., Paton, V. O. (2014). An effective leader in higher education. Journal of International Education and Leadership, 4, 2.

7. Martinez, M., Wolverton, M. (2009). Innovative Strategy Making in Higher Education. IAP.

8. McClure, K. R. (2016). Building the innovative and entrepreneurial university: An institutional case study of administrative academic capitalism. The Journal of Higher Education, 87, 4.

9. Morgan, J., Mulligan, C. T. (2014). When university partners with local governments in innovative ways. Public Management, 96, 10, 17-20.

10. Najam, A., Hendrix, C., Tan, K. P. (2014). Leaders in higher education. Foreign Policy, 209, 2-11.

11. Piemonte, R. (2015). An innovative leader aimed at developing the best and brightest. The American Nurse, 47, 3, 13-27.

12. Stenmark, Ch. K., Shipman, A. S., Mumford, M. D. (2011). Managing the innovative process: The dynamic role of leaders. Psychology of Aesthetics, Creativity, and the Arts, 5, 1, 67-80.

13. Varol, A., Varol, S. (2012). Transformational and transactional leaders: A case study in the higher education. Proceedings of the International Conference on Intellectual Capital, Knowledge Management \& Organizational Learning (p. p. 279-285). Database: Business Source Comple.

14. Vlăsceanu, Ch. (2013). The importance of an innovative leader in the organization. Annals of the University of Oradea, Economic Science Series, 22, 2, 703-709. 
10. Weiss, D. S., Legrand, C. (2011). Innovative Intelligence: The Art and Practice of Leading Sustainable Innovation in Your Organization. John Wiley \& Sons Canada.

11. Yagging, T., Huiyu, Y, Li, S. (2015). Mode of government-enterprise-university-institute-employer cooperation for innovative postgraduate cultivation. Universal Journal of Educational Research, 3, 2, 9398.

15. Zuber-Skerritt O. (2013). Professional Development in Higher Education: A Theoretical Framework for Action Research. Routledge.

\title{
INNOVATIVE LEADER IN HIGHER EDUCATION
}

Vytautas Katasanovas, Vidmantas Katasanovas, Žilvinas Stankevičius

Lithuanian Sports University, Kaunas, Lithuania

\begin{abstract}
Research background. Changing higher education environment, global competition of universities and colleges, need to react to the changes in labour market created new challenges for higher education institutions, that must implement innovations that help to keep their activity effective and improve it. One of the traits of effective leadership is innovative leadership in higher education institution that is especially oriented towards implementing changes in universities and colleges. Challenges for higher education institution in the context of innovations are widely determined in scientific literature. It is important to identify what are the roles of innovative leader in higher education, and to research the level of innovative leadership in Lithuanian higher education institutions. The object of the research is the innovative leader in higher education.
\end{abstract}

Goal of research is identify main roles of innovative leader in higher education and to determine how they manifest at higher education organization "Kauno kolegija".

Methods of research. Methods of analysis and systemising were used performing theoretical literature analysis. Method of questionnaire survey was used to perform an empirical research, that is, to evaluate how roles of innovative leader manifest at higher education institution "Kauno kolegija" $(\mathrm{n}=49)$. Questionnaire was prepared, Cronbach's Alpha $=0.76$.

Results and findings. Analysis of theoretical literature revels that working with people is an important part of innovative leader's agenda. Such a leader should use style of transformational leadership (idealized influence, inspirational motivation; intellectual stimulation, individualized consideration). On the other hand, innovative leader should take part in innovation process. He should initiate important innovations that would improve higher education environment (help a university or college to correspond to challenges of our times; implement new methods of activity and education; stimulate meaningful researches; implement innovations that prepare students for international and internal labour market), and also take part in planning and executing innovations.

Results of empirical research performed in higher education institution "Kauno kolegija" reveal that innovative leadership is yet not fully implemented in this organization. Abilities of formal leaders to act as innovative leader and work with people as a transformational leader are not sufficient. Leaders in this organization do not take an adequate role starting innovations that would help organization to cope with challenges of our times, management innovation, or innovations helping students to become prepared for international labour market is rather weak. 


\section{Main conclusions:}

1. Innovative leader should play two main roles in higher education organization: working with people using the style of transformation leadership; and working with innovation process, stimulated right innovations corresponding to the challenges in higher education institution's environment.

2. Abilities of formal leaders in higher education institution "Kauno kolegija" to act as innovative leader and work with people as a transformational leader are not sufficient; role of innovative leaders in implementing innovations that help institution to cope with challenges in the environment is rather weak.

Keywords: innovative leader; innovation; higher education; higher education institution. 